\title{
RESILIENSI PEREMPUAN DENGAN KEHAMILAN TIDAK DIINGINKAN DI KOTA BANDUNG
}

\author{
Jean Klara Paliyama \\ Politeknik Kesejahteraan Sosial Bandung, jeanpaliyama@gmail.com \\ Ellya Susilowati \\ Politeknik Kesejahteraan Sosial Bandung, ellyasusilowati1@gmail.com
}

\begin{abstract}
Resilience is a person's ability to survive, rise, and adapt to difficult conditions. This study aims to examine the resilience of women with unwanted pregnancies at the Hope Growing House Foundation, Bandung City, West Java. The aspects studied include 1) Informant Characteristics 2) Emotion Regulation 3) Impulse Control 4) Analysis of Causes of Problems 5) Reaching Out. This study uses a descriptive qualitative approach to three informants JR, L, ENS and one social worker namely ADK. Data collection techniques used in-depth interviews, observation and documentation studies.

The results showed that the informants had less resilience due to unwanted pregnancy. The aspect of resilience that is lacking is emotional regulation where at the beginning of pregnancy the informant thought to commit suicide and in the aspect of impulse control the informant experienced trauma. To overcome this, the researcher designed a "Resilience Strengthening Program for Women with unwanted pregnancies through the Educational Group." The purpose of the program is to increase resilience. Women with unwanted pregnancies can gain knowledge about postnatal mental health and infant care training skills so that they are ready to become mothers.
\end{abstract}

Keywords: Resilience, Women With Unwanted Pregnancy

\begin{abstract}
Abstrak
Resiliensi merupakan kemampuan seseorang untuk bertahan, bangkit, dan menyesuaikan dengan kondisi yang sulit. Penelitian ini bertujuan untuk mengkaji mengenai Resiliensi Perempuan dengan Kehamilan Tidak Diinginkan di Yayasan Rumah Tumbuh Harapan Kota Bandung Provinsi Jawa Barat. Aspek-aspek yang diteliti meliputi 1) Karakteristik Informan 2) Regulasi Emosi 3)Pengendalian impuls 4)Analisis Penyebab Masalah 5)Reaching Out. Penelitian ini menggunakan pendekatan kualitatif deskriptif terhadap tiga informan JR, L, ENS dan satu orang pekerja sosial yaitu ADK. Teknik pengumpulan data yang digunakan wawancara mendalam, observasi dan studi dokumentasi. Hasil penelitian, menunjukkan bahwa informan memiliki resiliensi yang kurang akibat kehamilan tidak diinginkan. Aspek resiliensi yang kurang yaitu regulasi emosi dimana pada awal kehamilan informan berfikir untuk bunuh diri dan pada aspek pengendalian impuls informan mengalami trauma. Untuk mengatasi hal tersebut Peneliti merancang"Program Penguatan Resiliensi Perempuan dengan kehamilan tidak diinginkan melalui Educational Group" Tujuan program yaitu untuk meningkatkan resiliensi Perempuan dengan kehamilan tidak diinginkan dapat memperoleh pengetahuan tentang kesehatan mental pasca melahirkan dan keterampilan pelatihan perawatan bayi sehingga mereka siap menjadi ibu.
\end{abstract}

Kata Kunci :Resiliensi, Perempuan Dengan Kehamilan Tidak Diinginkan 


\section{PENDAHULUAN}

Anak adalah seseorang yang belum berusia 18 (delapan belas) tahun, termasuk anak yang masih dalam kandungan (pasa1 1, UU no 35 tahun 2014). Setiap anak berhak atas kelangsungan hidup, tumbuh dan berkembang serta berhak atas perlindungan dari kekerasan dan diskriminasi sebagaimana diamanatkan dalam Undang-Undang Dasar Negara Republik Indonesia Tahun 1945.

Namun demikian fenomenanya terdapat banyak kasus kehamilan yang tidak diinginkan, sehingga terjadi palanggaran hak hidup dan perlindungan anak dalam kandungan. Data jumlah kehamilan tidak diinginkan yang dilaporkan kepala BKKBN pada tahun 2020 masih cukup tinggi di Indonesia yaitu rata-rata nasional $17,5 \%$.

Kehamilan yang tidak diinginkan diantaranya dapat disebabkan kekerasan seksual, pergaulan bebas, permerkosaan, pola asuh orang tua, pergaulan, kehidupan ekonomi keluarga, lingkungan, dan lain sebagainya (Fajrina, D. D. , 2012; Zebua, N. S. Y. 2021; Purnama, Y.2020).

Dampak kehamilan yang tidak diinginkan dapat mempengaruhi kondisi psikologis McKenry, Walters dan Johnson (dalam Papalia dan Olds, 2001) juga menyatakan bahwa kehamilan pada remaja putri yang tidak diinginkan memiliki dampak tertentu seperti ketidaksiapan untuk melahirkan. Ketidaksiapan tersebut sangat mempengaruhi kondisi psikologis remaja putri.

Kepala UPT Pusat Pelayanan Terpadu Pemberdayaan Perempuan dan anak (P2TP2A) Kota Bandung juga mengatakan bahwa pada tahun 2019 hingga pertengahan tahun sudah tercatat sebanyak 104 kasus kehamilan tidak diinginkan akibat kekerasan seksual yang dialami oleh perempuan. Dari kasus yang dilaporkan terdapat Perempuan yang mengalami kehamilan tidak diinginkan memilih untuk tetap melanjutkan kehamilan walaupun dengan konsekuensi mendapatkan aib dan tekanan masyarakat. Perempuan tersebut merasakan perasaan malu, sedih, kecewa, rasa bersalah, tertekan dan perasaan negatif lainnya, tetapi mereka tidak membiarkan perasaan perasaan negatif berada dalam dirinya berlarut-larut.

Perempuan yang mengalami kehamilan tidak diinginkan berusaha untuk bertahan dan bangkit dari keadaan yang tertekan. Kemampuan untuk mengatasi, beradaptasi serta bertahan dalam keadaan tertekan dan bahkan berhadapan dengan kesengsaraan (adversity) atau trauma yang dialami dalam kehidupannya disebut resiliensi (Reivich dan Shatte, 2002).

Secara etimologis Resiliensi di adaptasi dari kata dalam Bahasa Inggris resilience yang berarti daya lenting atau kemampuan untuk kembali dalam bentuk semula (Poerwadarminta, 1982). Sedangkan Reivich \&Shatte (2002:102) selanjutnya menyatakan bahwa resiliensi merupakan kemampuan seseorang untuk bertahan, bangkit, dan menyesuaikan dengan kondisi yang sulit. Resiliensi juga 
merupakan a kapasitas untuk merespon secara sehat dan produktif ketika berhadapan dengan kesengsaraan atau trauma, yang diperlukan untuk mengelola tekanan hidup sehari-hari.

Faktor-faktor yang mempengaruhi resiliensi dikemukakan oleh Reivich dan Shatte (2002), adalah: 1) regulasi emosi, yaitu kemampuan untuk tetap tenang di bawah kondisi yang menekan. Individu yang memiliki kemampuan mengatur emosinya dengan baik dan memahami emosi orang lain akan memiliki self-esteem dan hubungan yang lebih baik dengan orang lain (Greef, 2002: 20); 2) Pengendalian Impuls, yaitu kemampuan individu untuk mengendalikan keinginan, dorongan, kesukaan, serta tekanan yang muncul dari dalam diri. (Reivich dan Shatte, 2002: 21): 3) Causal Analysis merujuk pada kemampuan individu untuk mengidentifikasikan secara akurat penyebab dari permasalahan yang mereka hadapi. Individu yang tidak mampu mengidentifikasikan penyebab dari permasalahan yang mereka hadapi secara tepat, akan terus menerus berbuat kesalahan yang sama: 4) Reaching out adalah kemampuan individu meraih aspek positif atau mengambil hikmah dari kehidupan setelah kemalangan yang menimpa. Banyak individu yang tidak mampu melakukan reaching out, hal ini dikarenakan mereka telah diajarkan sejak kecil untuk sedapat mungkin menghindari kegagalan dan situasi yang memalukan.

Perempuan yang resilien akan berusaha dengan sekuat tenaganya untuk bangkit dan menghadapi kesulitan atas kehamilan tidak diinginkannya bahkan mampu mengatasi kesulitannya tersebut dan mengubahnya menjadi sesuatu yang positif. Oleh sebab itu, ada perempuan yang mampu bertahan dan pulih dari situasi negatif secara efektif dan ada perempuan lain yang gagal karena mereka tidak berhasil keluar dari kesulitan atas kehamilan tidak diinginkannya. Secara umum, resiliensi bermakna kemampuan seseorang untuk bangkit dari keterpurukan yang terjadi dalam kehidupannya. Individu dengan resiliensi yang positif mampu mengelola emosi mereka secara sehat.

Perempuan tersebut juga mampu menyesuaikan diri dengan keadaan yang tidak menyenangkan, melewati keadaan yang tidak menyenangkan tersebut dengan baik bahkan menerima kehamilan yang tidak diinginkannya untuk menjadi bagian dari hidupnya dengan merawat kehamilan hingga anak tersebut besar. Proses pengambilan keputusan sampai perempuan dapat menerima kenyataan dan bertanggung jawab sebagai orang tua serta menjadi orang yang lebih baik merupakan salah satu kemampuan individu yang resilien. Resiliensi juga dapat diartikan sebagai kapasitas untuk beradaptasi dengan kesulitan hidup dan dianggap sebagai ukuran subjektif dari respons ini yang mencakup konsep-konsep seperti kekuatan batin, kompetensi, dan fleksibilitas. Ini mungkin berhubungan terbalik dengan depresi, persepsi stres, dan kecemasan (Alves, A. C., Cecatti, J. G., \& Souza, R. T. 2021).

Ciri utama pribadi dengan resiliensi tinggi berkisar pada kemampuan mempertahankan perasaan positif dan juga kesehatan serta energi. Individu yang resilien juga memiliki kemampuan memecahkan masalah yang baik, Berkembangnya harga diri, konsep diri dan 
kepercayaan diri secara optimal. Oleh karena itu, resiliensi merupakan faktor penting dalam proses perkembangan psikologis untuk kembali memperbaiki keadaan dan menerima kenyataan bagi perempuan yang mengalami kehamilan tidak diinginkan.

Kasus Kehamilan yang tidak diinginkan yang terjadi pada perempuan karena kekerasan seksual maupun ditinggal pasangannya juga dapat dilihat di Kota Bandung pada Yayasan Rumah Tumbuh Harapan atau yang sering disebut RUTH. Berdasarkan data yang ada di Yayasan RUTH menyebutkan bahwa jumlah Perempuan dengan kehamilan tidak diiginkan pada tahun 2018 yang ditangani ada 96 kasus dan meningkat menjadi 120 kasus pada tahun 2019 namun pada tahun 2020 mengalami penurunan menjadi 36 kasus. Berdasarkan presentase kasus dari 2011-2020 18\% dilakukan oleh mahasiswa, 20\% dilakukan oleh pelajar, $37 \%$ dilakukan wanita dibawah 20 tahun, $46 \%$ dilakukan wanita 20-29 tahun, $82 \%$ dilakukan bersama kekasih dan $5 \%$ pria tidak bertanggung jawab. Saat ini ada 8 orang klien di Yayasan Rumah Tumbuh Harapan yang menangani 3 klien yang sudah melahirkan dan 5 klien dengan usia kehamilan 6-9 bulan.Yayasan Rumah Tumbuh Harapan Kota Bandung menampung semua Perempuan yang mengalami masalah kehamilan yang tidak dikehendaki, mereka semua di asuh, dibimbing,dibina untuk pembentukan mental dan karakternya yang lebih baik dan resilien pasca kehamilan yang tidak diinginkan itu terjadi.

Peristiwa atau kejadian kehamilan yang tidak diinginkan pada setiap Perempuan yang ada di Yayasan Rumah
Tumbuh Harapan Kota Bandung ini merupakan korban dari kekerasan seksual ataupun ditinggal oleh pasangannya setelah mereka mengalami kehamilan. Sehingga pada umumnya mereka mengalami gangguan emosi atau kondisi emosi yang tidak stabil, rapuh, putus asa, depresi, gampang tersinggung, juga perasaan sedih karena harus jauh dari keluarga mereka karena komunikasi dengan orang luar yang dibatasi kecuali berkomunikasi dengan keluarganya. Hal ini juga didukung dari usia klien yang ditangani ada yang masih tergolong remaja awal dimana secara emosionalnya tidak stabil.

Kemudian di Yayasan Rumah Tumbuh Harapan ada beberapa klien juga yang mengalami tekanan terhadap kenyataan bahwa mereka akan memiliki anak dan menjadi seorang ibu. Selain tekanan yang dialami oleh klien yang sedang hamil, tekanan yang sama juga dialami oleh beberapa klien yang telah melahirkan mereka merasa mentalnya belum siap untuk keluar dari Yayasan Rumah Tumbuh Harapan dan kembali kedalam kehidupan masyarakat pasca mereka mendapatkan pelayanan di yayasan ini. Pelayanan yang diberikan oleh Yayasan Rumah Tumbuh Harapan adalah pelayanan dengan tujuan stop aborsi. Dimana pelayanan ini dilakukan untuk menekan angka aborsi anak dan sebaliknya meningkatkan hak hidup dari calon anak itu sendiri sesuai dengan UU Perlindungan Anak (Pasal 4) bahwa setiap anak berhak untuk dapat hidup, tumbuh, berkembang dan berpartisipasi secara wajar sesuai dengan harkat dan martabat kemanusiaan, serta mendapat perlindungan dari kekerasan dan 
diskriminasi. Sehingga berdasarkan dengan UU Perlindungan Anak (pasal 4) tersebut setiap anak dari Perempuan dengan kehamilan tidak diinginkan di yayasan Rumah Tumbuh Harapan memiliki hak hidup yang melekat pada diri setiap anak dimulai dari dalam kandungan ibunya hingga anak itu lahir, sehingga anak-anak tersebut harus dijamin hak hidupnya dan tidak boleh di aborsi.

Melihat kondisi emosional setiap calon ibu yang mengalami kehamilan tanpa direncanakan maupun diinginkan bukan suatu hal yang gampang, sehingga membutuhkan kemampuan untuk tetap tenang dan mengendalikan diri dalam situasi yang sulit seperti ini. Untuk itulah, mereka perlu dibimbing dan di asuh untuk menjadikan mereka perempuan yang penuh dengan arti hidup yang lebih baik, serta menjadikan mereka sebagai individu yang resilien dalam menjalankan hidup di tengah banyaknya problematik yang mereka alami.

Berdasarkan latar belakang tersebut, maka penulis melakukan penelitian tentang resiliensi perempuan dengan Kehamilan Tidak Diinginkan Di Kota Bandung Indonesia. Secara aspek-aspek yang dibahas dalam penelitian ini adalah: 1) karakteristik informan ; 2) cara informan membangun Regulasi Emosi dalam dirinya untuk menghadapi permasalahan yang dialaminya: 3) Pengendalian implusdalam menghadapi permasalahannya; 4) Bagaimana informan menganalisis permasalahan yang dihadapinya

\section{METODE}

Penelitian ini menggunakan metoda kualitatif, yaitu dengan sumber data nya ialah kata-kata, dan tindakan, selebihnya adalah tambahan seperti dokumentasi dan lain-lain (Lofland (2012: 157). Sumber data yang digunakan adalah: 1) sumber data primer yaitu informan dan Pekerja Sosial di Yayasan Rumah Tumbuh Harapan; dan 2) Sumber data sekunder yaitu data yang dikumpulkan untuk melengkapi data primer yaitu data tertulis, catatan klien, observas dan studi dokumentasi kegiatan.

Penentuan sampel dalam penelitian ini dilakukan secara purposive, yaitu dengan kriteria perempuan yang sedang mempertahankan kehamilannya diluar nikah yang mendapatkan pelayanan dari Yayasan Rumah Tumbuh Harapan. Hasil rekomendasi dari dari Lembaga ada 3 orang perempuan yang mereka datang ke Lembaga karena ingin mempertahankan kehamilannya. Informan lainnya adalah satu orang Pekerja Sosial yang menangani klien, sehingga mengetahui tentang kondisi resiliensi perempuan yang memepertahankan kehamilannya.

2. Teknik Pengumpulan data yang digunakan adalah:

a. Wawancara Mendalam (In-dept Interview) untuk mengetahui untuk mengetahui informasi terkait dengan aspek-aspek dari resiliensi. Wawancara mendalam ini selain dilakukan langsung kepada informan, juga dilakukan melalui zoom.

b. Menulis surat terkait dengan pengalaman mereka dalam kasus kekerasan sehingga mereka mengalami kehamilan yang tidak di inginkan.

c. Teknik Observasi Partisipatif, dimana peneliti terlibat langsung pada kegiatan sehari-hari informan sehingga mengetahui bagaimana 
regulasi emosi mereka selama hamil di luar keinginan, bagaimana pengendalian impuls, kemampuan menganalisis sebab akibat dalam mempertahankan kahamilan yang tidak diinginkan.

d. Studi Dokumentasi, dengan mempelajatri catatan kasus terkait dengan resiliensi perempuan dengan kehamilan tidak diinginkan di Yayasan Rumah Tumbuh Harapan

\section{Teknik Pemeriksaan dan Keabsahan Data}

Untuk menjamin keabsahan data yang diperoleh peneliti, maka teknik pemeriksaan keabsahan data yang digunakan antara lain :

a. Trianggulasi Sumber, yaitu dilakukan pengecekan data kepada keluarga informan baik dilingkungan tempat tinggal maupun dilingkungan tempat informan lainnya

b. Trianggulasi teknik, dengan melakukan beberapa teknik pengumpulan data baik wawancara, observasi dan studi dokumentasi.

c. Trianggulasi waktu, yaitu melakukan pengecekan data dalam berbagai rentang waktu misalnya pagi, siang, dan sore tentang situasi resiliensi dari informan.

Adapun cara yang digunakan dalam triangulasi adalah sebagai berikut:

(1) Membandingkan data hasil pengamatan dengan data hasil wawancara mendalam terdapat kesesuain atau tidak.

(2) Membandingkan apa yang dikatakan informan di depan umum dengan apa yang dilaktakan secara pribadi terdapat kesusaian atau tidak.

(3) Membandingkan hasil wawancara mendalam mendalam dengan isi suatu dokumen yang bersangkutan terdapat kesesuaian atau tidak.

\section{Teknik Analisa Data}

Analisis data dilakukan secara kualitatif sejak sebelum memasuki lapangan, selama di lapangan, dan setelah selesai di lapangan.

1) Data reduction (reduksi data), yaitu memilih hal-hal yang pokok, memfokuskan pada hal-hal yang penting, dicari tema dan polanya.

2) Data display (penyajian data)

Setelah data direduksi maka selanjutnya yang dilakukan adalah menyajikan data. Penyajian dapat berupa uraian naratif, maupun menghubungkan antar kategori.

3) Conclusion drawing or verification, yaitu menyimpulkan hasil kesimpulan

\section{HASIL PENELITIAN}

\section{1 .Karakteristik Informan}

Karakteristik informan dalam penelitian yang dilakukan, terdiri dari nama, umur, status serta pendidikan terakhir dan pekerjaan informan. Berikut merupakan karakteristik informan yang disajikan di dalam matriks 3.1 yaitu :

\begin{tabular}{|l|l|l|l|l|l|}
\hline No. & Informan & Smur & Status & $\begin{array}{l}\text { Pendidikan } \\
\text { Terakhir }\end{array}$ & Pekerjaan \\
\hline 1. & JR & $\begin{array}{l}27 \\
\text { Thn }\end{array}$ & Klien & SMA & $\begin{array}{l}\text { Pegawai } \\
\text { Swasta }\end{array}$ \\
\hline 2. & L & $\begin{array}{l}30 \\
\text { Thn }\end{array}$ & Klien & SMP & TKW \\
\hline 3. & ENS & $\begin{array}{l}15 \\
\text { Thn }\end{array}$ & Klien & SMP & Pelajar \\
\hline 4. & ADK & $\begin{array}{l}25 \\
\text { Thn }\end{array}$ & Staf & S1 & $\begin{array}{l}\text { Pekerja } \\
\text { Sosial }\end{array}$ \\
\hline
\end{tabular}

\section{Regulasi Emosi Informan}

Regulasi emosi dalam hal ini adalah kondisi emosional yang dirasakan oleh informan setelah dia mengetahui bahwa dirinya sedang hamil. Dan kehamilan itu tidak informan inginkan. Hasil wawancara dengan tiga informan yang dilakukan oleh 
peneliti secara luring ditemukan bahwa regulasi emosi ketiga informan sebagai berikut :

\begin{tabular}{|c|c|c|c|c|}
\hline \multirow{2}{*}{ Sub Aspek } & \multirow{2}{*}{ Temuan Tema } & \multicolumn{3}{|c|}{ Informan } \\
\hline & & JR & $\mathbf{L}$ & ENS \\
\hline $\begin{array}{l}\text { Cara informan } \\
\text { mengatur } \\
\text { emosinya ketika } \\
\text { mengetahui } \\
\text { bahwa dirinya } \\
\text { sedang hamil. }\end{array}$ & Pasrah dan Ikhlas & & & \\
\hline \multirow{3}{*}{$\begin{array}{l}\text { Perasaan } \\
\text { informan setelah } \\
\text { mengetahui } \\
\text { bahwa infroman } \\
\text { sedang hamil }\end{array}$} & $\begin{array}{l}\text { 1. Panik, sedih dan } \\
\text { kecewa }\end{array}$ & & & \\
\hline & 2. Kaget banget & & & \\
\hline & 3. Menyesal dan & & & \\
\hline \multirow{2}{*}{$\begin{array}{l}\text { Respon } \\
\text { pasangan } \\
\text { informan ketika } \\
\text { mengetahui } \\
\text { bahwa informan } \\
\text { hamil }\end{array}$} & \begin{tabular}{|ll}
1. & Tidak \\
gung jawab & \\
\end{tabular} & & & \\
\hline & $\begin{array}{ll}2 . & \text { Bertanggung } \\
& \text { jawab secara } \\
& \text { materi }\end{array}$ & & & \\
\hline \multirow{3}{*}{$\begin{array}{l}\text { Cara Informan } \\
\text { memberitahukan } \\
\text { bahwa dirinya } \\
\text { hamil kepada } \\
\text { orangtua } \\
\text { informan }\end{array}$} & $\begin{array}{l}\text { 1. Memberi tahu } \\
\text { keluarga }\end{array}$ & & & \\
\hline & $\begin{array}{l}\text { 2. Tidak memberi } \\
\text { tahu keluarga }\end{array}$ & & & \\
\hline & $\begin{array}{lll}\text { 3. } & \begin{array}{l}\text { Keluarga tahu } \\
\text { sendiri }\end{array} \\
\end{array}$ & & & \\
\hline \multirow[b]{2}{*}{$\begin{array}{l}\text { Respon } \\
\text { orangtua } \\
\text { informan setelah } \\
\text { mengetahui } \\
\text { kehamilan } \\
\text { informan }\end{array}$} & 1. Aborsi & & & \\
\hline & $\begin{array}{l}\text { 2. Tidak ada respon } \\
\text { keluarga }\end{array}$ & & & \\
\hline \multirow{2}{*}{$\begin{array}{l}\text { Pernahkah } \\
\text { informan } \\
\text { mencoba untuk } \\
\text { bunuh diri atau } \\
\text { menggugurkan } \\
\text { kandungan }\end{array}$} & $\begin{array}{l}\text { 1. Berfikir untuk } \\
\text { bunuh diri }\end{array}$ & & & \\
\hline & $\begin{array}{llr}\text { 2. } & \text { Tidak } & \text { berfikir } \\
& \text { untuk } & \text { bunuh } \\
\text { diri } & \\
& \end{array}$ & & & \\
\hline \multirow{2}{*}{$\begin{array}{l}\text { Siapa saja yang } \\
\text { sering } \\
\text { memberikan } \\
\text { support kepada } \\
\text { informan. }\end{array}$} & $\begin{array}{l}\text { 1. Mendapatkan } \\
\text { support }\end{array}$ & & & \\
\hline & $\begin{array}{l}2 . \\
\text { mendapatkan } \\
\text { support }\end{array}$ & & & \\
\hline $\begin{array}{l}\text { Hal apa yang } \\
\text { informan } \\
\text { lakukan ketika } \\
\text { informan stres } \\
\text { menghadapi } \\
\text { masalah } \\
\text { kehamilan ini. }\end{array}$ & Mencari solusi & & & \\
\hline
\end{tabular}

\begin{tabular}{|l|l|l|l|r|}
\hline Pandangan & 1. Pandang hina dan & & & \\
informan & & & & \\
terhadap diri & 2. Pasrah & & & \\
informan, saat \\
informan berada \\
dalam masalah & & & & \\
ini. & & & & \\
\hline
\end{tabular}

Berdasarkan dengan Matriks diatas dapat dilihat mengenai cara regulasi emosi informan hingga pandangan informan terhadap diri informan saat informan mengetahui bahwa dirinya dalam kondisi kehamilan tidak diinginkan. Berdasarkan dengan matriks diatas yang memiliki kekurangan untuk regulasi emosi ketiga informan yaitu ada dua informan yang merasa trauma dengan kehamilan yang mereka alami tetapi ketiga informan tetap mencari solusi untuk memecahkan permasalahan mereka. Secara rinci mengenai regulasi emosi ketiga informan dijelaskan sebagai berikut :

Cara regulasi emosi informan JR yaitu dengan pasrah dan ikhlas dalam menjalani proses kehamilannya walaupun pada awal kehamilan JR sempat merasa panik, sedih, dan kecewa saat mengetahui bahwa dirinya hamil serta respon pasangannya yang tidak bertanggung jawab dengan kehamilannya. Setelah menerima respon dari pasangan kemudian informan JR memberitahu keluarganya mengenai kehamilannya JR harus menerima salah satu respon dari tantenya yang menyarankan JR untuk melakukan aborsi, selain saran dari tantenya ada pemikiran informan untuk bunuh diri sekaligus pandangan hina dan remeh terhadap diri sendiri. Namun ditengah keadaan informan JR ini, dia masih mendapatkan support dari teman dan orang tua temennya sehingga JR mampu menerima kondisinya secara pasrah dan 
ikhlas kemudian mencari rumah singgah. Dalam kasus JR ini jika dilihat dari pengertian regulasi emosi menurut Greef, 2002: 20, maka dapat dilihat bahwa JR memiliki kemampuan regulasi emosi karena informan JR mampu untuk mengatur emosinya dengan baik dan memahami emosi orang lain.

Cara regulasi emosi informan $\mathrm{L}$ yaitu pasrah dan ikhlas dalam menjalani setiap proses kehamilan yang dialaminya. Walaupun awalnya $L$ merasa kaget dengan kehamilan yang dia alami. Namun dari respon pasangan yang tetap bertanggung jawab secara materi dalam membiayai proses kehamilan L sampai dia nanti melahirkan tidak membuat L berfikir untuk bunuh diri atau menggugurkan anaknya. Selain itu L tidak memberitahukan kepada keluarganya bahwa dirinya sedang hamil, sehingga tidak ada respon keluarga yang dapat membuat L terbebani. Hal ini juga didukung dengan pemberian support dari pasangan L. Hal ini membuat L memandang dirinya lebih kepada pasrah dalam menjalani setiap proses kehamilannya. Hingga pada akhirnya L memutuskan untuk mencari rumah singgah sebagai solusi dari permasalahannya. Dalam kasus L ini jika dilihat dari pengertian regulasi emosi menurut Greef, 2002: 20, maka dapat dilihat bahwa L memiliki kemampuan regulasi emosi karena informan L mampu untuk mengatur emosinya dengan baik dan memahami emosi orang lain.

Cara regulasi emosi informan ENS sama seperti dengan informan JR dan L, ENS lebih kepada pasrah dan ikhlas dalam menjalani setiap proses kehamilannya. Walaupun perasaan ENS pada awal mengetahui bahwa dirinya hamil, ENS merasa menyesal dan kecewa pada dirinya sendiri. Hal ini diperburuk dengan respon pasangan yang tidak bertanggungjawab atas kehamilannya, keluarga mengetahui sendiri mengenai kehamilan ENS, disuruh aborsi, hingga ENS pernah berfikir untuk bunuh diri, selain itu tidak adanya support atau dukungan dari keluarga sehingga ENS lebih kepada memandang dirinya kearah pasrah dalam menjalani kehamilannya, sehingga ENS datang ke yayasan sebagai salah satu solusi mempertahankan bayinya dan juga menjaga nama baik keluarga ENS. Dalam kasus ENS ini jika dilihat dari pengertian regulasi emosi menurut Greef, 2002: 20, maka dapat dilihat bahwa ENS tidak memiliki kemampuan regulasi emosi karena informan ENS tidak mampu untuk mengatur emosinya dengan baik dan memahami emosi orang lain. Pasrah dan ikhlas dalam cara regulasi emosi yang dinyatakan oleh ENS adalah cara yang dilakukan atau dijalani karena ENS sudah tidak memiliki pilihan lain selain nurut dengan kemauan keluarganya.

\section{3 .Pengendalian implus}

Pengendalian implus dalam hal ini adalah kemampuan informan dalam mengendalikan dirinya setelah dia mengetahui bahwa dirinya sedang hamil. Dan kehamilan itu tidak informan inginkan. Hasil wawancara dengan tiga informan yang dilakukan oleh peneliti secara luring ditemukan bahwa pengendalian implus ketiga informan sebagai berikut :

\begin{tabular}{|l|ll|r|r|r|}
\hline \multirow{2}{*}{ Sub Aspek } & \multicolumn{2}{|c|}{ Temuan } & \multicolumn{3}{|c|}{ Informan } \\
\cline { 3 - 5 } & Tema & \multicolumn{1}{|c|}{ JR } & \multicolumn{1}{|c|}{ L } & ENS \\
\hline $\begin{array}{l}\text { Gambaran } \\
\text { perasaan }\end{array}$ & 1. & Merasa & $\checkmark$ & & $\checkmark$ \\
\hline
\end{tabular}




\begin{tabular}{|c|c|c|c|c|}
\hline $\begin{array}{l}\text { informan } \\
\text { setelah } \\
\text { beberapa } \\
\text { bulan } \\
\text { mengandung/ } \\
\text { melahirkan. }\end{array}$ & $\begin{array}{ll}\text { 2. } & \text { Tidak } \\
\text { sal } & \\
\end{array}$ & & & $\sqrt{ }$ \\
\hline $\begin{array}{l}\text { Setelah } \\
\text { kejadian ini, }\end{array}$ & $\begin{array}{l}\text { 1. Memiliki } \\
\text { Trauma }\end{array}$ & $\checkmark$ & & $\checkmark$ \\
\hline $\begin{array}{l}\text { apakah } \\
\text { informan } \\
\text { memiliki } \\
\text { trauma. }\end{array}$ & $\begin{array}{l}\text { 2. Tidak } \\
\text { Memiliki } \\
\text { Trauma }\end{array}$ & & $\bar{v}$ & \\
\hline $\begin{array}{l}\text { Cara } \\
\text { informan } \\
\text { mempertahan }\end{array}$ & $\begin{array}{l}\text { 1. Mencari } \\
\text { Rumah } \\
\text { Singgah }\end{array}$ & $\checkmark$ & $\sqrt{ }$ & $\bar{v}$ \\
\hline $\begin{array}{l}\text { kan } \\
\text { kehamilannya }\end{array}$ & $\begin{array}{l}2 . \\
\text { Mendeka } \\
\text { tkan Diri } \\
\text { Dengan } \\
\text { Tuhan }\end{array}$ & $\checkmark$ & & \\
\hline
\end{tabular}

Berdasarkan dengan Matriks diatas dapat dilihat bahwa pengendalian implus ketiga informan mulai dari gambaran perasaaan informan setelah beberapa bulan mengalami hamil sampai dengan cara informan untuk mempertahankan kehamilannya. Berdasarkan matriks diatas juga dapat dilihat bahwa kelemahan informan dalam pengendalian impuls yaitu masih ada 2 informan yang mengalami trauma setelah mereka mengalami kehamilan yang tidak mereka inginkan. Secara rinci kemampuan pengendalian impuls informan dapat dijelaskan sebagai berikut :

Gambaran perasaan informan JR setelah beberapa bulan menjalani masa kehamilannya, JR merasa enjoy dalam menjalani proses kehamilan yang awalnya tidak JR inginkan. Walaupun akhirnya dari kejadian kehamilan ini meninggalkan perasaaan trauma bagi JR untuk kembali hamil dan memiliki pasangan lagi. Upaya yang dilakukan JR untuk mempertahankan kehamilannya dengan mencari rumah singgah untuk dirinya serta lebih mendekatkan diri dengan Tuhan. Selama berada di rumah singgah JR tidak menunjukkan perilaku agresif, atau perilaku mudah marah, tetapi sebaliknya JR memiliki hubungan yang baik dengan sesama klien yang menerima pelayanan di yayasan. Hal ini dapat dilihat dari interaksi JR dengan klien yang lain di yayasan yang mau saling tolong-menolong dalam menjalankan piket harian, maupun mengikuti kegiatan bersama.

Gambaran perasaan informan $\mathrm{L}$ ketika awal kehamilan hingga beberapa bulan menjalani kehamilannya, informan merasa enjoy dalam menjalani masa-masa ini. Kejadian inipun tidak meninggalkan perasaan trauma terhadap informan. Cara informan untuk tetap mempertahankan hak hidup anaknya dengan mencari rumah singgah atau yayasan Rumah Tumbuh Harapan. Selama di yayasan informan L tidak pernah menunjukkan perilaku yang agresif ataupun perilaku mudah marah. Sebaliknya informan $\mathrm{L}$ dekat dengan informan yang lain, bahkan L sering memberi nasehat untuk informan yang masih muda di yayasan. Seperti dengan informan JR, informan L juga saat di yayasan memiliki interaksi yang baik dengan sesama klien di yayasan.

Gambaran perasaan ENS ketika sudah beberapa bulan menjalani masa kehamilannya, informan lebih merasa enjoy atau menikmati masa-masa kehamilannya ini. Walaupun pada awalnya informan ENS merasa menyesal dan kecewa dengan dirinya sendiri. Perasaan enjoy ini lebih kearah pasrah dengan keadaan dan tidak mau untuk membuat ayah ENS kecewa lagi. Walaupun akhirnya ENS memiliki perasaan trauma dengan kehamilan yang dijalaninya, trauma untuk memiliki pasangan, serta trauma untuk 
hamil lagi. Cara ENS mempertahankan kehamilannya, dicarikan rumah singgah agar kehamilan ENS tidak diketahui oleh keluarga besarnya. Selama berada di yayasan ENS tidak terlalu berbaur dengan teman-teman informan, karena informan memiliki pendengaran kurang baik sehingga informan ENS sulit untuk melakukan komunikasi dengan informan yang lain, informan $\mathrm{L}$ walaupun tidak memiliki interaksi yang baik dengan informan yang lain, namun informan tidak menunjukkan pelaku agresif maupun perilaku mudah marah sebaliknya ENS tetap menjalankan rutinitas di yayasan seperti biasanya.

\section{Analisis penyebab masalah}

Analisis penyebab masalah dalam hal ini adalah kemampuan informan dalam menganalisis penyebab dari permasalahan kehamilan yang tidak diinginkan oleh informan yang sedang dialaminya setelah informan mengetahui bahwa dirinya sedang hamil. Dan kehamilan itu tidak informan inginkan. Hasil wawancara dengan tiga informan yang dilakukan oleh peneliti secara luring ditemukan bahwa analisis penyebab masalah ketiga informan sebagai berikut :

\begin{tabular}{|c|c|c|c|c|}
\hline \multirow[t]{2}{*}{ Sub Aspek } & \multirow[t]{2}{*}{ Temuan Tema } & \multicolumn{2}{|c|}{ Informan } & pelajaran dalam \\
\hline & & JR & $\mathbf{L}$ & Eksidupnya. Selain itu JR berencana ketiga \\
\hline \multirow{2}{*}{$\begin{array}{l}\text { Pendapat } \\
\text { Informan } \\
\text { tentang } \\
\text { masalah yang } \\
\text { informan } \\
\text { hadapi }\end{array}$} & $\begin{array}{l}\text { 1. Tinggal Bersama } \\
\text { Pasangan }\end{array}$ & $\checkmark$ & & $\begin{array}{l}\text { keluar dari yayasan JR berencana untuk } \\
\text { mencari pekerjaan yang baik dan halal }\end{array}$ \\
\hline & $\begin{array}{l}\text { 2.Terlalu } \\
\text { Mempercayai } \\
\text { Pasangan }\end{array}$ & & & $\begin{array}{l}\text { unttuk menghidupi dirinya dan anaknya. } \\
\text { Harapan informan JR bahwa kedepannya }\end{array}$ \\
\hline \multirow{3}{*}{$\begin{array}{l}\text { Pelajaran } \\
\text { atau hikmah } \\
\text { yang } \\
\text { informan } \\
\text { pelajari dari } \\
\text { kondisi yang } \\
\text { sedangdi } \\
\text { hadapi saat } \\
\text { ini untuk }\end{array}$} & $\begin{array}{l}\text { 1. Tidak mau } \\
\text { salah jalan lagi }\end{array}$ & $\checkmark$ & & $\begin{array}{l}\text { yan \$ sama dan mengalami kehamilan tidak } \\
\text { diinginkan lagi. }\end{array}$ \\
\hline & $\begin{array}{l}\text { 2. Menjadikan } \\
\text { sebagai pelajaran }\end{array}$ & & & $\begin{array}{l}\text { Informan } \mathrm{L} \text { dalam menganalisis } \\
\text { permasalahan yang dihadapinya informan }\end{array}$ \\
\hline & $\begin{array}{ll}\text { 3. } & \text { Tidak mau } \\
\text { mengulangi } \\
\text { lagi }\end{array}$ & & & $\begin{array}{l}\text { berpendapat bahwa masalah yang } \\
\text { informan alami dikarenakan tinggal }\end{array}$ \\
\hline
\end{tabular}

\begin{tabular}{|l|l|r|r|r|}
\hline $\begin{array}{l}\text { bekal } \\
\text { menjalankan } \\
\text { hidupmu } \\
\text { kedepan }\end{array}$ & & & & \\
\hline $\begin{array}{l}\text { Rencana } \\
\text { Informan } \\
\text { kedepan yang } \\
\text { ingin } \\
\text { informan } \\
\text { lakukan. }\end{array}$ & $\begin{array}{c}\text { Rulang Ke } \\
\text { Rumah }\end{array}$ & & $\checkmark$ & $\checkmark$ \\
\hline $\begin{array}{l}\text { Harapan } \\
\text { informan } \\
\text { kedepan. }\end{array}$ & $\begin{array}{l}\text { Tidak ingin } \\
\text { mengulangi } \\
\text { kejadian yang sama }\end{array}$ & $\checkmark$ & & $\checkmark$ \\
\end{tabular}

Berdasarkan dengan diatas dapat dilihat bahwa analisis penyebab masalah ketiga informan mulai dari Pendapat Informan tentang masalah yang informan hadapi sampai dengan harapan-harapan informan kedepan. Berdasarkan dengan tabel 4.6 juga dapat dilihat bahwa ketiga informan mampu untuk melakukan analisis penyebab masalah yang mereka alami. Penjelasan mengenai analisis penyebab masalah yang dialami oleh informan akan dibahas lebih rinci sebagai berikut :

Informan JR dalam menganalisis permasalahan yang dihadapinya informan berpendapat bahwa masalah yang informan alami karena tinggal bersama dengan pasangannya. Pelajaran atau hikmah yang diambil oleh JR adalah JR tidak mau salah jalan lagi dan menjadikan ini sebagai sebuah pelajaran dalam ksidupnya. Selain itu JR berencana ketiga keluar dari yayasan JR berencana untuk unty menghidupi dirinya dan anaknya. unttuk menghidupi dirinya dan anaknya. Harapan informan JR bahwa kedepannya informan tidak ingin untuk mengulangi hal yan\& sama dan mengalami kehamilan tidak Informan alami dikarenakan tinggal 
bersama pasangannya di Dubai. Pelajaran atau hikmah yang diambil oleh informan bahwa informan menjadikan semua kejadian ini sebagai pelajaran, rencana informan kedepan adalah kembali ke Dubai untuk bekerja. Harapan kedepannya L tidak mau untuk mengulangi kejadian yang sama.

Analisis penyebab masalah oleh informan ENS, informan berpendapat bahwa permasalahan yang dialaminya disebabkan oleh ENS terlalu mempercayai pasangannya sehingga ENS setuju untuk melakukan hubungan seks dengan pasangannya. Pelajaran atau hikmah yang diambil dari kejadian ini adalah ENS Tidak mau mengulangi lagi kejadian yang dialami. Rencana informan kedepan akan kembali ke rumah untuk meminta maaf ke ayahnya sekaligus mempersiapkan diri untuk kembali ke sekolah lagi. Harapan informan kedepan tidak ingin mengulangi kejadian yang sama lagi.

\section{Reaching out}

Reaching Out dalam hal ini adalah kemampuan informan meraih aspek positif dari kehidupan setelah kemalangan yang menimpa. Dari permasalahan kehamilan yang tidak diinginkan oleh informan yang sedang dialaminya setelah mengetahui bahwa dirinya sedang hamil. Hasil wawancara dengan tiga informan yang dilakukan oleh peneliti secara luring ditemukan bahwa reaching out ketiga informan sebagai berikut :

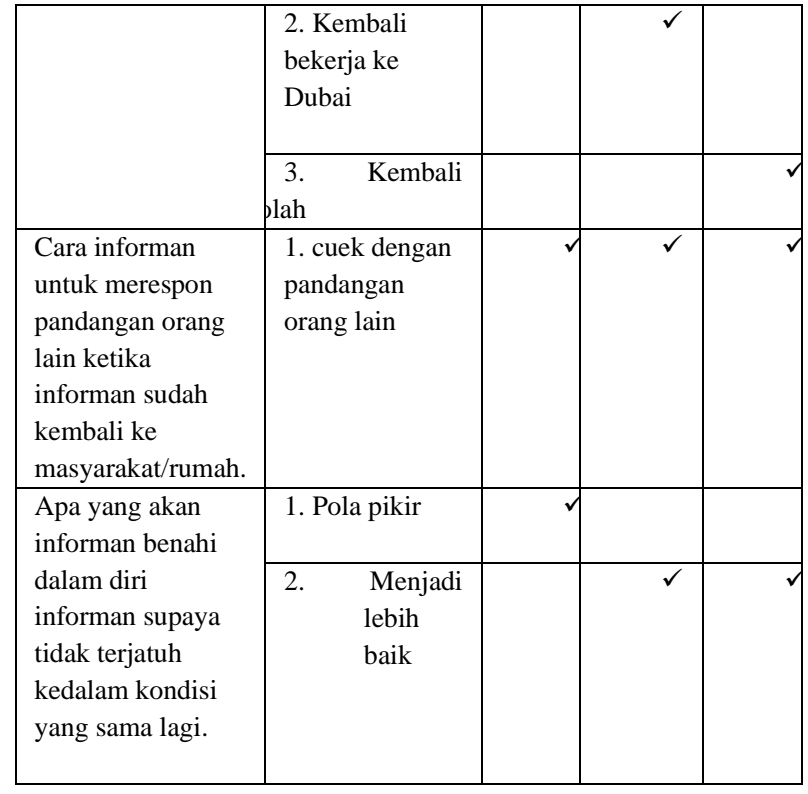

Berdasarkan dengan diatas dapat dilihat bahwa reaching out dari ketiga informan mulai dari hal yang akan dilakukan oleh informan ketika keluar dari yayasan hingga apa yang harus dibenahi dalam diri informan. Berdasarkan dengan tersebut dapat dilihat bahwa ketiga informan memiliki kemampuan reaching out dimana mereka mampu untuk memikirkan nasib mereka ketiga keluar dari yayasan, mampu untuk melihat apa yang perlu mereka benahi di dalam diri mereka. Secara rinci kemampuan reaching out ketiga informan akan dijelaskan sebagai berikut :

Kemampuan Reaching out dari informan JR dalam mengambil pelajaran atau hikmah dari kejadian yang dihadapinya sesuai dijelaskan pada aspek sebelumnya bahwa informan tidak mau salah jalan lagi seain itu hal yang dilakukan informan setelah keluar dari yayasan

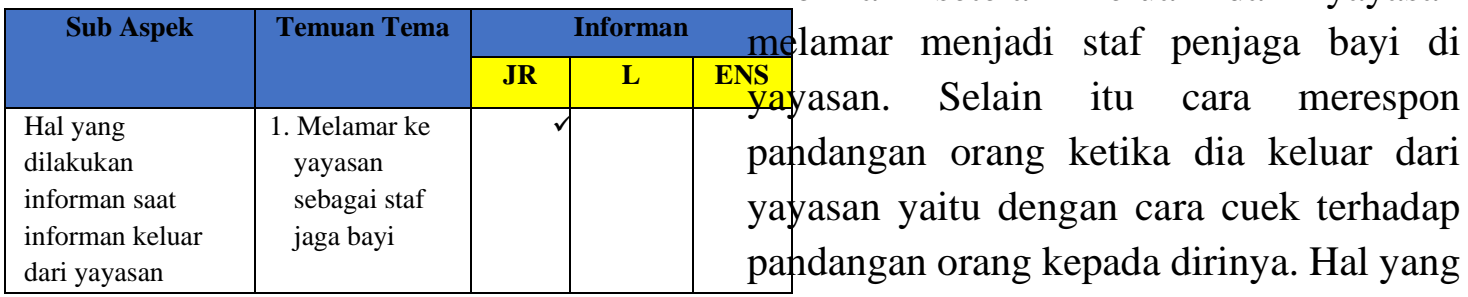


perlu dibenahi dari informan yaitu mengenai pola pikir klien JR.

Kemampuan Reaching out informan L dalam mengambil pelajaran atau hikmah dari kejadian yang dialaminya dapat dilihat pada aspek sebelumnya bahwa informan $\mathrm{L}$ menjadikan kejadian ini sebagai pelajaran dalam hidupnya. Hal yang akan dilakukan informan ketika keluar dari yayasan juga yaitu kembali bekerja ke Dubai, seperti dengan JR informan $\mathrm{L}$ merespon pandangan orang dengan cara cuek dalam menanggapi respon orang terhadap dirinya. Hal yang perlu dibenahi dalam diri $\mathrm{L}$ adalah kedepan dia harus lebih menjadi pribadi yang lebih baik.

Kemampuan Reaching out informan ENS dalam mengambil hikmah atau pelajaran dalam hidupnya dapat dilihat dari pembahasan sebelumnya bahwa informan tidak mau untuk mengulangi kesalahan yang sama lagi. Selain itu hal yang akan dilakukan ketika ENS keluar dari yayasan adalah kembali untuk bersekolah lagi. Cara menanggapi pandangan orang terhadap dirinya dengan perilaku cuek akan pandangan atau penilaian orang terhadap dirinya. Hal yang ENS benahi dalam dirinya yaitu dia harus menjadi pribadi yang lebih baik sehingga tidak mengalami hal yang sama lagi.

\section{PEMBAHASAN}

Hasil penelitian menunjukkan bahwa perempuan yang mengalami kehamilan tidak diinginkan memiliki resiliensi yang cukup baik jika dilihat dari empat aspek (regulasi emosi, pengendalian impuls, analisis penyebab masalah, reaching out) seperti dikemukakan oleh Reivich dan Shatte (2002), namun masih ada hambatan dalam aspek pengendalian impuls. Secara rinci dapat dianalisis sebagai berikut :

\section{Aspek Regulasi Emosi}

Berdasarkan dengan hasil penelitian dapat diketahui ternyata ketiga informan mampu untuk meregulasi dan mengendalikan emosi mereka dengan baik. Jika dikaitkan dengan kondisi informan dilapangan maka dapat disimpulkan bahwa ketiga informan memiliki kemampuan regulasi emosi yang baik walaupun pada masa awal kehamilan terdapat dua informan yang memiliki pemikiran untuk bunuh diri. Namun kedua informan ditambah dengan satu informan lain mampu untuk mencari solusi terhadap permasalahan yang mereka alami. Solusi atau jalan keluar yang mereka upayakan menunjukkan bahwa informan mampu untuk bertahan di masa krisis. Hal ini menunjukkan bahwa resiliensi menunjukkan bahwa mereka tetap memiliki upaya untuk mempertahankan kehamilan mereka. Dengan memiliki resiliensi yang tinggi cenderung memiliki lebih sedikit gejala depresi dan lebih seimbang secara emosional (Alves, A. C., Cecatti, J. G., \& Souza, R. T. ,2021).

2. Aspek pengendalian impuls

Berdasarkan dengan hasil penelitian dapat dilihat bahwa aspek pengendalian impuls kurang karena ada dua informan masih trauma setelah mengalami kehamilan yang tidak mereka inginkan. Menurut (Reivich dan Shatte, 2002: 21) yang dimaksud dengan pengendalian impuls yakni :

Pengendalian impuls adalah kemampuan individu untuk mengendalikan keinginan, dorongan, kesukaan, serta tekanan yang muncul dari dalam diri. Individu yang memiliki kemampuan pengendalian 
impuls yang rendah, cepat mengalami perubahan emosi yang pada akhirnya mengendalikan pikiran dan perilaku mereka. Mereka menampilkan perilaku mudah marah, kehilangan kesabaran, impulsif, dan berlaku agresif. Tentunya perilaku yang ditampakkan ini akan membuat orang di sekitarnya merasa kurang nyaman sehingga berakibat pada buruknya hubungan sosial individu dengan orang lain.

Berdasarkan dengan pengertian pengendalian impuls diatas jika dikaitkan dengan kondisi informan dilapangan maka dapat disimpulkan bahwa pengendalian impuls informan kurang hal ini karena ada dua informan yang memiliki perasaan trauma baik trauma untuk memiliki pasangan atau perasaan trauma untuk hamil lagi, sehingga ada informan yang berfikir untuk melakukan steril rahim ketika informan sudah melahirkan. Perasaan trauma ini muncul karena dari kedua informan takut untuk merasakan kecewa lagi serta ketakutan untuk mengalami kehamilan yang tidak mereka inginkan lagi. Dari pernyataan-pernyataan kedua informan dapat diketahui bahwa kedua informan tidak mampu untuk mengendalikan keinginan, dorongan, kesukaan serta tekanan yang muncul dari dalam diri mereka sehingga pada aspek pengendalian impuls mereka masih kurang.

\section{Analisis Penyebab Masalah}

Berdasarkan dengan pembahasan hasil penelitian dapat diketahui bahwa secara keseluruhan dari informan sudah dapat melakukan analisis dari penyebab masalah. Hal ini mendukung resiliensi perempuan dengan kehamilan tidak diinginkan. Hal ini seperti dikemukakan oleh (Reivich \& Shatte, 2002 : 21) bahwa: Analisis Penyebab Masalah merujuk pada kemampuan individu untuk mengidentifikasikan secara akurat penyebab dari permasalahan yang mereka hadapi. Individu yang tidak mampu mengidentifikasikan penyebab dari permasalahan yang mereka hadapi secara tepat, akan terus menerus berbuat kesalahan yang sama

Berdasarkan dengan pengertian
diatas dapat disimpulkan bahwa
keseluruhan informan memiliki kemampuan analisis penyebab masalah yang baik. Hal ini dapat dilihat melalui kemampuan informan dalam menganalisis sebab-akibat dari permasalahan yang mereka alami. Selain itu informan juga mampu untuk mengambil hikmah serta pelajaran dari kejadian yang dia alami dengan harapan bahwa keseluruhan informan tidak ingin untuk melakukan dan mengalami hal yang sama lagi.

\section{Reaching Out}

Dari hasil penelitian dapat diketahui bahwa hampir keseluruhan informan pada tahap ini menunjukkan bahwa mereka memiliki resiliensi yang baik. Seperti yang dikemukakan oleh (Reivich \& Shatte, 2002 : 22) bahwa :

Reaching out adalah kemampuan individu meraih aspek positif atau mengambil hikmah dari kehidupan setelah kemalangan yang menimpa. Banyak individu yang tidak mampu melakukan reaching out, hal ini dikarenakan mereka telah diajarkan sejak kecil untuk sedapat mungkin 
menghindari kegagalan dan situasi yang memalukan.

Berdasarkan dengan pengertian reaching out diatas hampir keseluruhan informan mampu untuk mengambil hikmah dan pelajaran dari kejadian kehamilan yang tidak mereka inginkan. Serta dapat meraih aspek positif dengan merencanakan apa yang akan mereka lakukan ketika mereka sudah keluar dari yayasan dan berniat untuk memperbaiki kehidupan mereka untuk menjadi pribadi yang lebih baik.

Dari aspek-aspek resiliensi tersebut dapat mendukung kelangsungan kehamilan informan agar dapat sampai selamat pada proses melahirkan dengan sehat dan dengan tidak mengalami trauma. Untuk itu $\mathrm{t}$ maka diperlukan intervensi untuk menguatkan resiliensi informan. Dari hasil penelitian maka diperlukan untuk menguatkan resiliensi perempuan yang mengalami kehamilam tidak diinginkan, yaitu dengan cara memberikan support dan dukungan kepada informan yang dilakukan oleh sesama informan di yayasan Rumah Tumbuh Harapan. Hal ini karena setiap informan mengalami permasalahan yang sama yaitu kehamilan yang tidak mereka inginkan sehingga dapat memberikan support satu sama lain karena pada dasarnya mereka sepenanggungan dan memiliki masalah yang sama sehingga mereka akan lebih mudah memahami satu sama lain.

Untuk menghilangkan trauma yanhg dialami informan dapat ditangani dengan melakukan proses konseling terhadap informan yang berada di yayasan Rumah Tumbuh Harapan. Konseling merupakan salah satu program yang telah dilaksanakan oleh yayasan dimana program konseling ini terbagi atas konseling kelompok dan konseling individu. Program konseling yang ada di Yayasan selama ini dari lebih ditingkatkan dan dioptimalkan lagi sehingga dapat mememenuhu kebutuhan paling mendasar dari setiap informan yang dimana perasaan trauma informan menjadi suatu permasalahan yang membutuhkan penanganan serius agar setiap informan ketika kembali ke masyarakat sudah mampu untuk menjalankan peran sosialnya serta dapat berfungsi sosial dengan baik lagi.

\section{Analisis Kebutuhan}

Berdasarkan dengan hasil penelitian dan analisis masalah maka untuk meningkatkan resiliensi perempuan dengan kehamilan tidak diinginkan diperlukan intervensi, supaya informan tidak trauma dan dapat melanjutkan kehidupannya setelah informan keluar dari yayasan, maka informan memiliki beberapa kebutuhan yaitu :

\section{a. Pemberian support dan dukungan kepada calon ibu.}

Pemberian support dan dukungan sangat dibutuhkan oleh keseluruhan perempuan yang menjalani masa-masa kehamilan mereka. Hal ini akan mendukung kesehatan calon ibu tersebut.

Memberikan support dan dukungan kepada informan dapat dilakukan oleh sesama informan di yayasan Rumah Tumbuh Harapan. Hal ini karena setiap informan mengalami permasalahan yang sama yaitu kehamilan yang tidak mereka inginkan sehingga dapat memberikan support satu sama lain karena mereka sepenanggungan dan memiliki masalah 
yang sama sehingga mereka akan lebih mudah untuk memahami satu sama lain. Melalui pemberian support dan dukungan ini juga diharapkan dapat menjadi media informan dalam menyampaikan keluh kesah, permasalahan serta kebutuhankebutuhan dari informan. Sehingga informan tidak merasa sendiri dalam menghadapi permasalahannya.

b. Meningkatkan fokus pendampingan dari staf dalam mengatasi trauma yang dialami oleh informan

Kondisi trauma informan yang berada di yayasan, membuat mereka mengalami tekanan, dan tidak percaya diri sehingga membawa mereka pada situasi dimana tidak ingin menjalin hubungan dan mengalami kehamilan kembali. Hal ini sehingga informan membutuhkan pendampingan dari petugas untuk bersama-sama mengatasi trauma informan.

Trauma ini dapat ditangani dengan melakukan proses konseling terhadap informan yang berada di yayasan Rumah Tumbuh Harapan. Di Yayasan ini konseling merupakan salah satu program yang telah dilaksanakan oleh yayasan dimana program konseling ini terbagi atas konseling kelompok dan konseling individu. Namun walaupun konseling telah diterapkan, belum mampu untuk mengatasi permasalahan trauma yang dihadapi oleh para informan yang menerima pelayanan. Untuk itu peneliti berharap bahwa untuk program konseling dari yayasan lebih ditingkatkan dan dioptimalkan lagi sehingga dapat menyentuh kebutuhan dan permasalahan paling mendasar dari setiap informan, yang dimana perasaan trauma informan menjadi suatu permasalahan yang membutuhkan penanganan serius, terencana, dan dilakukan secara konsisten agar setiap informan mampu untuk mengatasi perasaan trauma mereka sehingga ketika mereka kembali ke masyarakat mereka sudah mampu untuk menjalankan peran sosialnya serta dapat berfungsi sosial dengan baik lagi.

\section{Analisis Sumber}

Untuk mendukung dan mengatasi permasalahan tersebut maka diperlukan sumber-sumber baik formal, informal, dan kemasyarakatan menurut Pincus dan Minahan dalam Dwi Heru Sukoco (1991:38-39) yaitu :

\section{a. Sistem sumber informal}

Sistem sumber informal merupakan sumber yang dapat memberikan bantuan berupa dukungan emosional, afeksi, dan nasihat informasi dan pelayanan-pelayanan konkrit. Sumber ini tidak menggunakan prosedur dalam penggunaannya, sifatnya ikhlas, jujur, cinta kasih dan tanpa pamrih. Sumber informal dapat berupa keluarga, teman, tetangga, mitra kerja maupun orang lain yang dapat membantu. Sistem sumber informal yang dapat digunakan dalam mengatasi permasalahan kehamilan tidak diinginkan yang dialami oleh informan yang berada di yayasan Rumah Tumbuh harapan yaitu :

1. Keluarga Para Perempuan diharapkan dapat mendampingi dan memberikan penguatan agar korban dapat menghadapi masalahnya dan menjaga kondisinya agar tetap stabil

2. Sesama perempuan yang mengalami hamil di luar tanggungan Yayasan Rumah Tumbuh Harapan diharapkan dapat saling menguatkan satu sama lain.

3. Pengurus yayasan Rumah Tumbuh Harapan diharapkan dapat mendampingi, membimbing serta 
memberikan saran dan arahan kepada setiap informan.

4. Masyarakat yang tinggal di sekitar yayasan diharapkan dapat menjaga kondisi dan suasana lingkungan tempat tinggal supaya setiap informan tidak merasa mendapat stigma dan diskriminasi.

\subsubsection{Sistem sumber formal}

Sistem sumber formal adalah keanggotaannya di dalam suatu organisasi atau asosiasi formal yang dapat memberikan bantuan atau pelayanan secara langsung kepada anggotanya dalam suatu organisasi atau asosiasi formal. Sumber ini dapat digunakan apabila telah memenuhi persyaratan yang ditentukan oleh sumber tersebut. Sumber formal biasanya berbentuk lembaga formal, seperti organisasi, serikat buruh, koperasi, bank dan asosiasi profesional. Sistem sumber informal yang bisa digunakan untuk membantu klien menyelesaikan permasalahan yaitu Yayasan Rumah Tumbuh Harapan Kota Bandung.

\subsubsection{Sistem sumber kemasyarakatan}

Sistem sumber kemasyarakatan merupakan sumber berupa lembaga pemerintah maupun swasta yang dapat memberikan bantuan pada masayarakat umum. Sumber yang dapat dikelompokkan dalm system sumber kemasyarakatan seperti sekolah, rumah sakit, programprogram latihan kerja dan pelayanan kesejahteraan sosial. Sistem sumber kemasyarakatan yang bisa digunakan untuk membantu informan dalam penyelesaian permasalahan informan di yayasan yaitu Rumah Sakit, Balai Latihan Kerja, Dinas Sosial, Dinas Kesehatan, P2TPA Bandung.

\section{KESIMPULAN}

Berdasarkan dengan hasil penelitian maka dapat diketahui resiliensi setiap informan Perempuan dengan kehamilan tidak diinginkan diketahui bahwa resiliensi bagi perempuan yang hamil tidak diingikan merupakan modal yag penting dalam memelihara kehamilan dan kesehatan bayi mereka,

Kemampuan Regulasi emosi dilihat dari hasil penelitian dapat diketahui ternyata ketiga informan mampu untuk meregulasi dan mengendalikan emosi mereka dengan baik. Walaupun pada masa awal kehamilan terdapat dua informan yang memiliki pemikiran untuk bunuh diri. Namun kedua informan ditambah dengan satu informan lain mampu untuk mencari solusi terhadap permasalahan yang mereka alami. Solusi atau jalan keluar yang mereka upayakan menunjukkan bahwa informan mampu untuk bertahan di masa krisis. Di masa ini mereka tetap memiliki upaya untuk mempertahankan kehamilannya.

Kondisi tersebut juga dapat dilakukan untuk meningkatkan pengendalian impuls agar perempum yang hamil perlu dilatih

Kemampuan analisis dari penyebab masalah berdasarkan dengan pembahasan hasil penelitian dapat diketahui bahwa secara keseluruhan dari informan sudah dapat melakukan analisis dari penyebab masalah. Hal ini mendukung resiliensi perempuan dengan kehamilan tidak diinginkan. Keseluruhan informan memiliki kemampuan analisis penyebab masalah yang baik. Hal ini dapat dilihat melalui kemampuan perempuan yang hamil tersebut sudah mampu menganalisis sebab-akibat dari permasalahan yang mereka alami. Selain itu informan juga mampu untuk mengambil hikmah serta 
pelajaran dari kejadian yang dia alami dengan harapan bahwa keseluruhan informan tidak ingin untuk melakukan dan mengalami hal yang sama lagi.

Ketiga informan dilihat dari hasil penelitian dapat diketahui bahwa hampir keseluruhan informan pada tahap ini menunjukkan bahwa mereka memiliki resiliensi yang baik. Hampir keseluruhan informan mampu untuk mengambil hikmah dan pelajaran dari kejadian kehamilan yang tidak mereka inginkan. Serta dapat meraih aspek positif dengan merencanakan apa yang akan mereka lakukan ketika mereka sudah keluar dari yayasan dan berniat untuk memperbaiki

\section{DAFTAR PUSTAKA}

Alex. 2003. Psikologi Umum. Bandung: Pustaka Setia Enung Fatimah. . 2003.

Alves, A. C., Cecatti, J. G., \& Souza, R. T. (2021). Resilience and stress during pregnancy: A comprehensive multidimensional approach in maternal and perinatal health. The Scientific World Journal, 2021doi:http://dx.doi.org/10.115 5/2021/9512854

Adi Fahrudin. 2012. Pengantar Kesejahteraan Sosial. Bandung: PT Refika Aditama

Budi Wibawa. 2010. Dasar-Dasar Pekerjaan Sosial. Bandung: Widya Padjajaran

Desmita, 2009.Psikologi Perkembangan.

Bandung: Remaja Rosda Karya

-daya-lenting-resilience-pada-perempuan-

k.pdfdiakses tanggal 15 Agustus 2020 pukul 20:34 WIT

-daya-lenting-resilience-pada-perempuank.pdfdiakses tanggal 15 Agustus 2020 pukul 20:34 WIT

Fajrina, D. D. (2012). Resiliensi pada remaja putri yang mengalami kehamilan tidak diinginkan akibat kekerasan kehidupan mereka untuk menjadi pribadi yang lebih baik.

Untuk meningkatkan resiliensi pada Perempuan dengan kehamilan tidak diinginkan dapat diajukan program "Penguatan Resiliensi Perempuan dengan kehamilan tidak diinginkan melalui kegiatan Education Group" Tujuan program tersebut yaitu untuk meningkatkan resiliensi Perempuan dengan kehamilan tidak diinginkan dapat memperoleh pengetahuan tentang kesehatan mental pasca melahirkan dan keterampilan pelatihan perawatan bayi sehingga mereka siap menjadi ibu.

seksual. JPPP-Jurnal

Penelitian dan Pengukuran

Psikologi, 1(1), 55-62.

Garvin. 2011. Group Work. Bandung: STKS Press

Husaini.1995. Metodologi Penelitian

Sosial. Jakarta: Bumi Aksara.

Kartini. 2002. Psikologi Perkembangan. Jakarta : Rineka Cipta

Lexy.2011.Metodologi Penelitian Kualitatif. Bandung:ROSDA

Poerwadarminta.1982.Kamus Besar Bahasa Indonesia. Jakarta: Balai Pustaka

Purnama, Y. (2020). Faktor Penyebab Seks Bebas Pada Remaja. Syntax Literate; Jurnal Ilmiah Indonesia, 5(2), 156-163.

Reivich, K \& Shatte, A. 2002. The Resilience Factor ; 7 Essential Skill For Overcoming Life's Inevitable Obstacle. New York, Broadway Books

Sugiyono. (2011). Metode penelitian kuantitatif dan R \& D .Bandung: Alfabeta.

Sturgeon, J.A., and Zautra, A.J. 2010.Resilience: A New 
Paradigm for Adaptation to Chronic Pain.

Current Pain and Headache Reports,

Vol.14, No.2, 105-112.

Worell, Judith dan Remer, Pam (1992).

Feminist Persp ectives in Therapy, an

Empowerment Models For Women.

Chichester: John Wiley and sons

Zebua, N. S. Y. (2021). Pendampingan

Psikososial Terhadap Perempuan Hamil Di

Luar Nikah. HINENI: Jurnal Ilmiah

Mahasiswa, 1(1), 21-28.

https://www.bkkbn.go.id diakses tanggal 15

Agustus 2020 17:35 WIT

https://id.wikipedia.org/wiki/Resiliensi diakses tanggal 15 Agustus 2020 pukul 21:15WIT

http://yurikamaha.blogspot.com/2016/05/siste

m-sumber-menurut-allen-pincus-

and.html diakses tanggal 9 Agustus 2021

pukul 04:56 WIB

http://justinlase.blogspot.com/2017/02/pekerja an-sosial-dengan-kelompok-group.html diakses tanggal 11 Agustus 2021 pukul 10:20 WIB

https://nasional.kompas.com/read/2020/06/30/

15030631/bkkbn-kehamilan-tak-

diinginkan-di-indonesia-rata-rata-175-

persen diakses 30 Agustus 2021 pukul

12:06 WIB 